821.163.41.09:398

https://doi.org/10.18485/mks_srpska_slavistika.2018.2.ch24

\author{
Валентина Д. ПИТУЛИЋ* \\ Универзитет у Приштини \\ са привременим седиштем \\ у Косовској Митровици \\ Филозофски факултет
}

\title{
НАРОДНЕ УМОТВОРИНЕ СРБА СА КОСОВА И МЕТОХИЈЕ ОД ИВАНА СТЕПАНОВИЧА ЈАСТРЕБОВА ДО ПОСЛЕДЬИХ ЗАПИСА
}

\begin{abstract}
У раду се бавимо прегледом записа народних умотворина Срба са Косова и Метохије од појаве прве збирке Ивана Степановича Јастребова па до последњих записа студената Катедре за српски језик и књижевност Филозофског факултета Универзитета у Приштини са привременим седиштем у Косовској Митровици. Богат корпус песама са ове територије научној јавности био је углавном непознат јер се у време систематског записивања народних умотворина Вука Караџија није могло лако доћи на територију Старе Србије која је била под турском влашћу. Појавом збирке Ивана Степановича Јастребова европској јавности је презентовано до тада научним круговима напознато фолклорно усмено наслеђе које је било једно од примарних у сагледавању колективног усменог наслеђа словенских народа. Показаћемо како је текао процес записивања народних умотворина Срба на Косову и Метохији од записа Ивана Степановича Јастребова (преко записа у Цариградском гласнику, Дене Дебељковића, Јанићија Поповића, Глише Елезовића, Бранислава Нушића, Владимира Бована) па све до последњих студентских записа.

Кључне речи: народне умотворине, Иван Степанович Јастребов, лирика, епика, говорне народне творевина, колектив, Стара Србија, Косово и Метохија, фолклор.
\end{abstract}

Усмено наслеђе Срба са Косова и Метохије представља саставни део усменог стваралаштва Срба уопште. Наталожено колективно искуство нашло је свој одраз у уметности речи, која је била део обредно-обичајне праксе и слика свеукупног живота колектива и појединца. Усмено наслеђе Срба са Косова и Метохије записивано је у распону од отприлике век и по, а то је фонд од око 4800 записа. Почетком тридесетих година 19. века прве песме са Косова и Метохије забележио је Вук Стефановић Караџић, који није обишао Стару Србију, али је у Крагујевцу 1821. године,

*valentina.pitulic@pr.ac.rs 
од свог певача Анђелка Вуковића из села Орахова код рудника Трепче забележио пет песама. Овај запис је значајан јер је Анђелко Вуковић Вуку казивао епске песме, а Косово и Метохија је лирски крај, тако да је ово сведочење да је на Косову и Метохији било епског певања (у белешци уз песму Змија Младожења у предговору књиге Народне српске пјесме (Лајпциг 1823) и у Рачуну јуначких песама у књизи Народне српске пјесме (Беч 1833). Вуковог певача са Косова поменуо је и Атанасије Урошевић у својој књизи Косово (1965: 92). Од Анђелка Вуковића Вук је записао следеће песме: Мајстор Манојло (Караџић 1846: 45), две о ускоцима: Женидба Ива Сењанина (Исто, песма бр. 26) и Млади Марјан и Арнаут Осман (Исто, песма бр. 27) и једну новију, о одбрани манастира Дечана од пљачкаша из Скадра, Jaym-бег и Перо Мркоњић (Исто, IV, песма бр. 16). Овим песмама треба додати и епску песму приповедног карактера Змија младожења (Исто, песма бр. 12).

У овим крајевима се сигурно певало и пре Косовске битке. С обзиром на то да је ово била територија у којој је било седиште царевине, постојали су сви услови за неговање лирске народне песме, која је имала и обредни и обичајни карактер, али је било и љубавних, посленичких и других лирских врста. Из овог периода имамо сачуване богате лирске врсте, али и јуначке песме које су биле другачијег садржаја од оних после Косовске битке. То што је било мање епских песама о догађајима пре Косовске битке треба тражити у ставу Вука Стефановића Караџића:

„Ја мислим да су Србљи и прије Косова имали и јуначких пјесама од старине, но будући да је она премјена тако силно ударила у народ, да су готово све заборавили, што је било донде, па само оданде почели наново приповједати и пјевати” (Караџић 1824: 37).

Словенац Бенедикт Курипечић на путовању према Цариграду 1530. године прошао је кроз Косово и оставио драгоцене податке о јуначкој народној песми о Косовском боју на месту где се битка догодила. Посебно је важно што је он тада оставио податке о родољубивом осећању Срба који су се надали да ће им хришћани помоћи:

„Ти исти Срби које затекосмо у хришћанској вери, указаше нам много љубави. Тако би по који старац долазио к нама и говорио младима: „Видите каква су господа била у овој земљи за вријеме наших отаца. Ах, Боже, ми смо се увијек надали да ћете нас ослободити” (Курипечић 1530: 32).

Византијски писац Критовул оценио је Србе на овај начин: „Србија има красно становништво и особито ратоборну омладину” (Радонић 1930: 74)

Како је Косово и Метохија изразито лирски крај, прва збирка народних песама је збирка лирских песама, која је на крају прве половине 19. века настала у Пећи. Записивач је био анониман. Ова збирка представља прву збирку (Вуксан 1938: 244-252) народних песама насталу на територији Косова и Метохије. У овом периоду записана је још једна песма коју је у Великој Хочи забележио Геодон Јуришић (1852). У другој половини 19. века почиње подробније интересовање за усмено наслеђе Срба на Косову и Метохији и појављивање првих штампаних збирки: Ивана Степановича Јастребова (Ястребовъ 1886), Дене Дебељковића (Дебељковић 1907; Бован 1984), ${ }^{1}$ Бранислава Нушића (1902-), Стевана Мокрањца (1966), Јанићија

\footnotetext{
${ }^{1}$ Дена Дебељковић, рукопис: Народне песме са Косова, Етнографска збирка САНУ, бр. 10.
} 
Поповића², Косте Манојловића (1933: 44-47), Владимира Ђорђевића $(1928,1931)$, Љубице и Данице Јанковић $(1929,1934,1937,1948,1949,1951,1952,1964)$ и Миодрага Васиљевића (1950). Други запис лирске народне песме датира из 1865. године (Срећковић 1865: 72-73), а прва (непоуздана) збирка Милоша Милојевића (1869, $1870,1875)$ штампана је 1869 . године.

Најзначајнија, најаутентичнија и најобимнија збирка настала је у другој половини 19. века, а то је збирка руског конзула у Призрену, Ивана Степановича Јастребова (Ястребовъ 1886). Убрзо је изашло и друго издање (1889), у којем је додато још педесет нових лирских народних песама. Јастребов је објавио српске народне песме и две песме на турском језику. Његов рад био је веома значајан јер је записивао у тренутку када су народне умотворине доживеле свој врхунац како у броју песама тако и у естетском смислу. Рад Ивана Степановича Јастребова, како наводи Владимир Бован, био је веома значајан јер „седамдесетих и осамдесетих година деветнаестог века у ове крајеве под Турском није [се] могло долазити са стране, а поготову не из Србије, ради истраживачких подухвата" (1996: 7).

Појава збирке Ивана Степановича Јастребова била је од великог значаја јер је први пут европска научна јавност упозната са усменим наслеђем Срба у тадашњој Турској и што се на основу сакупљеном материјала могла извршити реконструкција целокупног духовног живота Срба са ове територије. Велики руски научник, Веселовски, бавио се посебно верским народним песмама упоредивши их са румунским, грчким и бугарским. Он се бавио и појединачним песмама налазивши симболе који указују на индоевропско порекло. Јастребов је забележио велики број ђурђевданских песама, а Веселовски показује њихову велику сличност са руским и румунским, а о велигданским песмама писао је Димитрије Николски у свом приказу Јастребовљеве књиге (Николский 1886).

Јастребов је подробно писао о обичајима у околини Призрена и у књизи их објављује овим редом: слава, преслава, свети Игњат, коледа, бадње вече, Божић, Мали Божић и Василица, Богојављење, Св. Јован, Бела недеља, велики пост, лазарице, велика недеља, Ускрс, Ђурђевдан, Јеремијин дан, Бела среда, додоле, Видовдан, жетва, обичајне песме, моравске песме гуслара, сватовски обичаји и песме, песме за светог Николу зимског, обичаји при рођењу детета, погребни обичаји.

Значај Јастребовљевој књизи дао је и руски научник Пипин (1886: 895-897), који је за ову збирку рекао да она представља допринос прве врсте у проучавању народне поезије у словенском контексту. Он наводи да је значај ове књиге у томе што је први пут скренута пажња на усмено стваралаштво Срба, о којем се у науци ништа није знало, а за Јастребов је по његовом мишљењу бољи познавалац овог стваралаштва него српски научници, што је и разумљиво с обзиром на то да се у ове крајеве није могло лако долазити. Опширан приказ Јастребовљеве књиге дао је и Ровински (1866: 382-405), који је упознао научну јавност са богатим пределима Старе Србије, оценивши Јастребовљеву књигу као крупан допринос у развоју науке, упоредивши је са књигом Вука Стефановића Караџића о Црној Гори (1837), Врчевићевом књигом о Боки, Херцеговини и Црној Гори (1890), књигом Милана

\footnotetext{
${ }^{2}$ Јанићије Поповић, Народни обичаји, умотворине и игре са Косова, Архив Матице српске, М. 7.538, рукопис.
} 
Милићевића о Кнежевини Србији (1876) и Петрановићевој књизи о Босни и Херцеговини $(1867,1870)$.

У очувању народног блага Срба са Косова и Метохије велики значај имали су у културни посленици; учитељи, свештеници, културни радници, који су имали осећај за богатство колективног наслеђа Срба на Косову и Метохији, па су своје записе објављивали у Цариградском гласнику, првом листу у тадашњој Турској, који је излазио само на турском језику. Први број Цариградског гласника изашао је 1895. године у Цариграду, а излазиће све до 1909. године. Био је ово лист где су културни посленици могли да објављују записе народних умотворина, али не и да покрећу политичке теме. Петар Митропан оставља следећи запис о Цариградском гласни$\kappa y:$ „Сва питања која су се третирала у Цариградском гласнику могу се обухватити двема речима: школа и вера, а ове две установе водиле су истом циљу - просвећивање масе, буђењу и одржавању у њој националне свести" (1895: 166). Објављивање народних умотворина било је у функцији буђења националне свести. У првим листовима објављиване су народне умотворине из Вукових збирки, али су касније објављиване и народне умотворине које су записивачи веродостојно записивали онако како се у народу приповедало. У овом једином гласнику на српском језику место су нашле лирске народне песме, пословице, изреке, загонетке, приповетке и бројанице. Од 247 лирских народних песама највише је обредних, затим љубавних, обичајних, посленичких, породичних, верских и родољубивих. Значај записивача је у томе што су поред песама записивали и обреде и обичаје који су их пратили, као важан моменат етнолошког богатства Срба у Старој Србији, а највише је обичаја везано за ђурђевске, ${ }^{3}$ лазаричке, славске и жетварске песме (наводимо песме онако како стоји у Цариградском гласнику и како су се називале у народу). Највише је записа из Средске и Сиринићке жупе, Пећи и околине, Призрена и околине. У Цариградком гласнику налазе се песме велике старине, посебно ђурђевске и велигданске. Обредне песме су сачувале древне симболе који указују на њихову старину. Од обредних песама заступљене су: коледарске, водичарске, ранилачке, лазаричке, на Цвети, велигданске, ђурђевске, спасовске, крстоношке. Нешто је мање обичајних песама (сватовске и славске), као и верских песама, али су оне изузетне лепоте јер се у њима преплићу пагански и хришћански мотиви. Посленичких је мало, углавном су жетелачке, али се за њих се може рећи, како каже Владимир Бован, да су антологијске (2006: 12).

Записивачи су забележили и породичне и родољубиве песме, док епских песама готово и да нема, из разумљивих разлога, јер је лист био под будним оком турских власти, а јуначке песме су углавном певале о бојевима против Турака. Епско-лирске, тј. приповедне песме биле су „безазленије” па је у Старом Колашину код Косовске Митровице забележена романса Стојан и Мирјана 4 . На страницама Цариградског гласника нашле су се и љубавне песме које су у тренутку записивања достигле највиши домет естетске вредности и у којима доминантно место припада девојци чија је лепота представљена устаљеним формулама. У Цариградском гласнику место су нашле и породичне песме у којима је опеван однос између мајке и

\footnotetext{
${ }^{3}$ Цариградски гласник, бр. 20, 1900, забележио Ђорђе Јакић, Цариградски гласник, 1901, бр. 17, забележио Радомир Шабић, Цариградски гласник 1899, бр.17, забележио Љубомир Спасић.

${ }^{4}$ Цариградски гласник, 1901, бр. 32, забележила Олга Лазић.
} 
ћерке, док је родољубивих песама мало, из разумљивих разлога политичких неслобода. Богатство лирских народних песама у Цариградском гласнику говори о још увек живој обредно-обичајној пракси уз преплитање древних симбола и хришћанске религије, као и радосно осећање живота, а њихова посебна вредност је што су испеване на дијалекту.

У Цариградском гласнику објављено је 16 приповедака (легенде, шаљиве приче, приче о животињама и новеле), док су од говорних народних творевина заступљене пословице, изреке, загонетке и бројанице и оне представљају важну грађу о животу Срба у Старој Србији. У њима је дата слика богатства свакодневног живота, где доминира висок степен духовности у окружењу великог броја манастира, али и свакодневних турских зулума. Богатство записа посебно чини и руковет бројаница које је Цариградском гласнику послао учитељ из Пећи Петар Д. Петровић. Цариградски гласник нуди и податке о месту записивања, као и о записивачима који су дешифровани тек у наше време, јер су се многи потписивали иницијалима или су слали под псеудонимом, бојећи се да Турци не открију свој идентитет. Да записи Цариградског гласника буду доступни данашњем читаоцу, потрудио се Владимир Бован, који је објавио записе у књизи Српске народне умотворине са Косова и Метохије на страницама Цариградског гласника.

Још једна значајна рукописна збирка народних умотворина појављује се крајем 19. века. Липљански свештеник, Дена Дебељковић, предаће рукопис (Бован 2006) Архиву САНУ у којем се налазе лирске и епске народне песме. Зборник лирских и епских песама из рукописа Дене Дебељковића објавиће Владимир Бован 1984. године. У предговору овог издања Владимир Бован даје податке о томе да се у рукописној заоставштини Дене Дебељковћа налазило преко седам стотина лирских и стотина епских песама. У првој објављеној књизи (приредио Владимир Бован) налазе се лирске и епске народне песме. Лирске врсте говоре о богатству народне обредно-обичајне праксе и у књизи се налазе следеће врсте: обредне песме (божићне, лазаричке, велигданске, ђурђевске, троичинске, додолске, крстоношке); обичајне (здравице, сватовске, верске, посленичке, љубавне, родољубиве). Епске песме: приповедне (легенде у стиховима, баладе, новелистичке песме); јуначке (преткосовске, косовске, песме о Марку Краљевићу, покосовске, песме о хајдуцима, песме о ускоцима). Осим збирке Дене Дебељковића у овом периоду појавило се неколико мањих збирки. После Другог светског рата рад на сакупљању народних умотворина наставиће Владимир Бован и објавиће их у десет књига под насловом Народна къижевност Срба на Косову (1980).

Иако је Косово и Метохија лирски крај, постоје подаци да је негована и епска народна песма. Податак о епском певању оставио је Миленко Филиповић, који је 1934. године посетио село Махуџир-Талиновце крај Урошевца. Он је том приликом слушао једног гуслара и оставља податак о томе да људи врло радо гуслају, како старији и млађи, тако и деца. Он примећује да пре певања песме гуслар одгусла увод, односно уводну епску формулу. Он даје податак о томе да је слушао гуслара, младића Станка Јевтића, и наводи да је особеност гуслања у томе што се последњи (десети слог) не изговара. Гуслар му је том приликом певао песму „Марко Краљевич и Муса Кесеџија” (Филиповић 1934: 260-262). Матија Мурко је, трагајући за народном епиком, 1930. године обишао Пећ, Ђаковицу, Призрен, Ораховац, Уроше- 
вац, Приштину, Лапље Село, Лепињу, Добротин, Доњу Гуштерицу, Липљан, Грачаницу, Косовску Митровицу, Звечан и Вучитрн и уочио да епска народна песма, упркос константном умирању, ипак још увек живи. Он оставља податке о певачима који су гуслали и наводи да се епска песма најбоље очувала у подримском срезу (Ораховац, посебно у селу Кијево и Дрсник), наводећи да се епске песме на Косову зову „старе”, „старе јуначке”, „старе од Косова”, „старинске” или „старовремске” (Мурко 1938: 565-576)

У другој половини 20. века на територији Косова и Метохије живела је обредно-обичајна пракса, али је била на сталном удару како комунистичких власти тако и деловања албанских структура које су својом политиком лагано затирале све што је имало предзнак српског. Међутим, записивање седамдесетих и осамдесетих година прошлог века добило је други облик. Записивачи су сада били студенти књижевности и језика на Филозофском факултету Универзитета у Приштини, који су одлазили на терен под менторством и руковођењем професора Народне књижевности, Владимира Бована ${ }^{5}$.

У записима студената нашао се највећи број обичајних песама, међу њима највише сватовских, које су у неким селима живеле у свом непромењеном облику, али су у срединама где је разорена патријархална заједница и даље чуване песме, иако је сватовски обичај нестајао под утицајем савременог начина живота. У оквиру сватовских обичаја било је доста здравица које су сачуване још из паганских времена. О сватовском обичају из Призрена и околине оставили су податке Иван Степанович Јастребов (Ястребовъ 1886) и Петар Костић (1928: 8-17, 76-81), из Липљана и околине Дена Дебељковић (1907: 185-221), а Јанићије Поповић ${ }^{6}$ из Грачанице. О сватовском обичају писали су и Бранислав Нушић, а о свадби из околине Пећи Коста Манојловић. О музичкој страни сватовских песама писали су Миодраг Васиљевић и сестре Јанковић. У записима студената нашле су се и верске, посленичке и родољубиве песме у којима су сачувани архаични облици колективне свести. У

\footnotetext{
${ }^{5}$ Седамдесетих и осамдесетих година XX века студенти Одсека за југословенску књижевност и српскохрватски језик, данас Одсек за српску књижевност и језик, Филолошког факултета у Приштини обавили су један врло значајан национални посао у сакупљању народних умотворина код Срба на Косову и Метохији, спасавајући их од заборава као неумитне судбине. Они су у својим семинарским радовима из Народне књижевности записали и саопштили, па тако и спасли од заборава на хиљаде народних песама, приповедака и говорних народних творевина (пословица, загонетака, изрека, питалица, клетви, заклетви, здравица и благослова, брзалица и др.). У 144 семинарска рада сто четрдесет и четворо студената је „ускладиштило” огромну грађу коју је народ српски на Косову и Метохији вековима стварао и вековима користио као своје најбоље средство против однарођавања од свог језика, веровања и свог српског имена. Сакупљањем народних умотворина, наводи Владимир Бован:

„заменили су једну српску научну институцију, која за Србе на Косову и Метохији није било и која није могла ни да се оснује само зато што би се бавила проучавањем српске културе, књижевности, историје, обичаја, обреда, веровања и живота Срба уопште, иако су Шиптари имали свој Албанолошки институт, основан још 1967. године. У студентским семинарским радовима, који су сачувани има 7411 записа народних песама, махом лирских, затим на стотине говорних творевина међу којима је највише изрека, пословица и загонетака. Студентски записивачи су направили сјајан снимак стања народног усменог стваралаштва код Срба на Косову и Метохији седамдесетих и осамдесетих година нашег века, који се више никада неће моћи поновити, с обзиром да је много те грађе коју су студенти забележили већ пропуштено забораву и засвагда нестало и из сећања најстаријих генерација. Старице и старци, певачи и казивачи тих народних умотворина студентима, већ почивају у свом миру" (Бован 2001: 5).

${ }^{6}$ Јанићије Поповић, Народни обичаји, умотворине и игре са Косова, Архив Матице српске, М, 7538.
} 
верским песмама се преплићу пагански и хришћански слојеви, док у посленичким доминирају жетелачке и косачке, али се оне често у студентским записима преплићу са љубавним. Како је у патријархалној заједници на Косову и Метохији била чврста породична задруга, то су и породични односи били веома чврсти, стога је сачуван велики број породичних песама. Занимљиво је да је у породичним песмама углавном опеван однос мајке према својој деци јер је она била средишња личност, али је са посебном топлином опеван однос брата према сестри.

У бројним родољубивим песмама опевана је љубав према отаџбини, која је изражена и у епским народним песмама, али је ово осећање посебно изражено у лирским народним песмама. Оне најбоље сликају осећање сталне жеље за слободом на територији која је била у вековном ропству. Велики број песама су љубавне, а приповедне и епске песме сведоче о томе да је усмено наслеђе Срба на Косову и Метохији очувано и у доба савремене културе друге половине 20. века јер је патријархална заједница у селу тешко прихватала савремени облик живота. Стара обредно-обичајна пракса споро се мењала и она је у одређеном друштвено-историјском тренутку била чувар идентитета.

Упоредо са лирским и епским песмама, као и другим народним умотворинама, на Косову и Метохији живеле су и приповетке, али се записи јављају релативно касно. Први запис приповетке настао је у првој половини 19. века, а касније ће се појавити још неколико записа (Вуксан 1935: 252; Веселиновић 1895: 41-42: Голуб 1895: 76-78; 1896: 119-121; 1897: 91-97; 1898: 83-94; Босанска вила 1898: 139). Прву збирку сачинио је Дена Дебељковић ${ }^{8}$ пред крај 19. века, која се састоји од преко стотину народних приповедака из липљанског краја. Најбројнију збирку оставио је Јанићије Поповић ${ }^{9}$ из Грачанице, док ће у периоду између два светска рата интересовање бити нешто веће јер су их научни истраживачи записивали ради лингвистичког истраживања, када је настало неколико рукописних збирки (Елезовић 1935 : 548-549; Павловић 1939: 242-259, 286-291; Алексић 1970; Владимир Цветановић, рукописна збирка; Бован 1980). Народне приповетке имале су живот сличан народним песмама и говорним народним творевинама. Последњи записи народних приповедака датирају из периода седамдесетих и осамдесетих година прошлог века, а то су записи студената Филозофског факултета Универзитета у Приштини које је приредио Владимир Бован (2005).

У истој књизи објављене су и говорне народне творевине. Студенти су на терену записивали преостале облике приповедачке прозе (приче о животињама и басне, легенде, скаске и предања, новеле, шаљиве приче, анегдиоте; а од говорних народних творевина пословице, изреке, питалице, брзалице, здравице, заклетве, клетве, бајалице и бројанице).

После бомбардовања Савезне Републике Југославије 1999. године под сталним притисцима албанског живља велики број Срба напустио је своја вековна огњишта и са њима је отишао један добар део усменог наслеђа. Живот преосталог народа

\footnotetext{
7 До краја XIX века објављено петнаестак народних приповедака.

8 Дена Дебељковић, Рукописна оставштина откривена у његовој личној архиви. Рукописи се налазе у Архиву САНУ, улазни инвентар бр. 644, Етнографска збирка бр. 496.

9 Јанићије Поповић, Народни обичаји, умотворине и игре са Косова, рукопис, Архив Матице српске у Новом Саду, бр. М. 7.538.
} 
који је остао да живи на територији под управом „мировних снага” организовао је свој живот у сеоским срединама. Поражавајуће је што је велики део усменог наслеђа Срба са Косова и Метохије заувек нестао пред лицем Европе, чији је учени свет у 19. веку учио српски језик да би у оригиналу читао српске народне песме.

Како више није било могућности за институционално записивања преосталих облика усменог казивања, посебно у оним срединама које су биле у потпуном албанском окружењу, на Филозофском факултету у Косовској Митровици студенти су наставили добру праксу коју је седамдесетих година прошког века започео професор Владимир Бован са својим студентина у Приштини. Студенти Катедре за српски језик и књижевност Филозофског факултета у Косовској Митровици су у првој деценији 21. века са терена доносили записе преосталих обичаја. лирских народних песама, приповедака и говорних народних творевина. Показало се да је фолклорно наслеђе још увек живо и да је чување колективног усменог наслеђа једини начин очувања идентитета Срба на Косову и Метохији. Последњи записи студената представљају богату грађу, чијом се анализом може направити увид у фреквентности појединих врста као и етнопсихолошка функција појединих врста у датом друштвено-историјском миљеу. Њихови записи су архивирани и чакају срећну околност да буду и публиковани.

У прилогу дајемо један од последњих студентских записа из Сиринићке жупе.

\section{ПРИЛОЗИ}

Записи из Сиринићке жупе, село Готовуша

У селу Готовуша сваке године празнује се Прочка (Беле покладе), а догађај који се приказује је женидба Марка Краљевића.

На Прочку, ујутру се сакупи омладина, муикарии, се маскиру, ће стају маске, рогове на главу, а овамо ће се обучу у кожушчић. Е ее'н се избере, се преруши у снашу, и после који су најврашки сељьни тија ће украдну снашу. Свако село имало своје вучаре и снашу. Е, па ће узу коње, чезе, и ће иду од село на село. После сви се враћу у своје село и се веселу, игру, поју. Млого било убаво.

Песма која се певала приликом поворке за Беле покладе:

Заспало ми Калинче, нане Калинче, Заспало ми Калинче, нане Калинче,

На вр'бело планинче, нане планинче, На вр'бело планинче, нане планинче На зелене ливаде, нане ливаде,

На зелене ливаде, нане ливаде,

На студене камене, нане камење, На студене камење, нане камење. Диг'се, диг' се Калинче, нане Калинче, Ниг'се, диг'се Калинче, нане Калинче, Доста си се наспало, нане наспало, Доста си се наспало, нане наспало, 
Три вечери без мене, нане без мене, Три вечери без мене, нане без мене.

Казивао Милорад Радић, село Готовуша, рођен 1931. године.

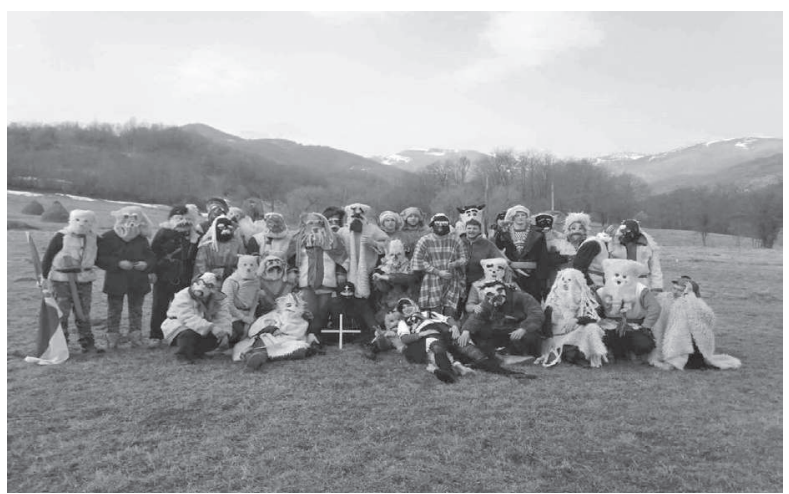

Вучари, 2017. год., село Готовуша

Лепосава Радић (село Готовуша, рођена 1930. године, домаћица) наставља причу:

Увече уземо кумбаре па ајд' сви на улииу. Цело село се сакупьало туј. Е после сваки запали своју кумбару и гу врти око себе, божем да растера духове. Кад се долази од улице, са све комиије се изљубимо и викамо: 'Ти да ми опростиш', а он одговара: 'Нека ти је просто'. Кад дођемо дома, напрајмо питу па се кадимо, вриимо обичај и запостујемо за Велигдан, јаја, сир, млеко, месо... све тој има на совру, јер од јутре се пости. А исто се обеси се на куку од зид јаје, и цела фамилија са уста ваћа јаје и кој га увати тој је његово, и узе паре.

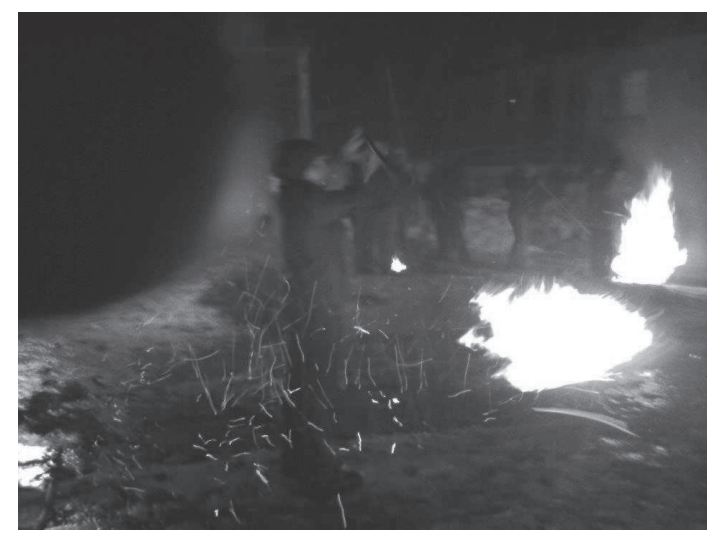

Беле покладе, „Мавање кумбаре”, село Готовуша, 2005. год. 


\section{Бадюи дан}

На Бадњи дан домаћин иде са сече бадњак и увече се уноси у кућу са све сламу и све се спраљ а посна храна, и домаћица га чека домачина са рукајиу пуну жито. Држи му врата и пита га: 'Какво је време на мегдан?' а он треба да одговори: 'Свуд ведрина над нашу кућу облачина.' и тако три пута. Е онда га пусти унутра и док уноси сламу и бадњак она га посипује са жито из рукајие, а деца сабиру жито од под. Домаћин стај бадњак да гори па после се заоди са омесен колач око астал, три круга и се вика: 'пиу, бау, му, бе...' све животиње се имитиру. Па се пева 'Господи помилуј',крии се колач, пије вино и узима ченица. Кад се заврии обичај, се ивади бадњак из огањ и се напива, домаћин му сипује вино озгор и вика: 'Здрав си бадњаче! -Наздравље јуначе! - Ти здрав ја никад не болан.' E, јутредан, ујутру најпрво од врапче уземо месо, мало га пресушимо и уземо дрен и вино и породчиа једе и вика: 'Да летимо ка врапче, да бинемо здрави ка дрен и ирвени ка вино'. После брат и сестра узу р'жану сламу да вржују око воћке, брат узе секирче и вика: 'Ће сечем', а сестра: 'Не, не, ће родим'. Тој у воћњак при дрво вику тој и туј сламу завржу на свако стабло да би родило воће теј године, еее тако било. И после у цркву ишле домаћини да носу врућу ракију па кад дођу дома јопе се вриија обичај. Разне песме се певале, и у јену кућу, кој има по голему одају идемо и разне игре играле се, на пример, љутике потпалу љуте и девојка рипа, ако ги помену име од симпатије она настави да рипа, а ако не онда застане, и се викало: Играј, играј јеженце.

Казивао Милорад Радић.

\section{Цветнице}

Ми кад смо биле девојке, ће се разбудимо рано ујутру па ће се промењамо. Ће обучемо народну ношњу, али не исту ка од Лазарице, него тад обучемо свилено кошуљче и ирну сукњу сас бошћиче и колан, па лично обујемо везене чарапе и опанце и онда идемо на игранку. И кад отинемо тамо, саберемо се сви и играмо и певамо разне песме, свака девојка пева коју песму највише воли, и тако.

\section{Велигдан}

По стари, пред Велигдан напрају ни нишало, како који има по више место, 'ал у двор, 'ал у воћњак, и онда ми деца а и девојке и момии ће се нишамо. И како кој дође на ред да се ниша, пева песму овако:

Лако трупче на орашче, лелајо, лелајо,

Чије да је, мајкино је, лелајо, лелајо,

Чије да је, татково је, лелајо, лелајо,

Мајку греје као Суние, лелајо, лелајо,

Татка греје као Месеи, лелајо, лелајо,

Доста си се нанишала, лелајо, лелајо,

Иу поље нагледала, лелајо, лелајо,

Све си момие избирала, лелајо, лелајо.

Казивала Лепосава Радић. 


\section{Спасовдан}

Утој старо време, ја кад сам бија млад, имале људи трла и много овце, а сви биле чобани. За Спасовдан, чобани се викале крстоноше јер секле лесковачу и од ьу правили крст. По више таква крста се прајле и јен би се стаја на врата, јен у башћу, а јен поносиле кад ишле кроз цело поље. И сви чобани крстоноше се скупу у поље и иду на бачење. Тамо бачица ги донесе сир, млеко и друго, стај на совру и кад поједу иду у трло и растуру место де спале овие, тој ги био ко обичај. На бачењу имале три кучета да чуву од вуце и кад крстоноше растуру тој трло, пушту теј кучиће да растеру дивљађију, вуце. Младе чобанице на Спасовдан певале песму 'Чувам овце крај зелене јове'.

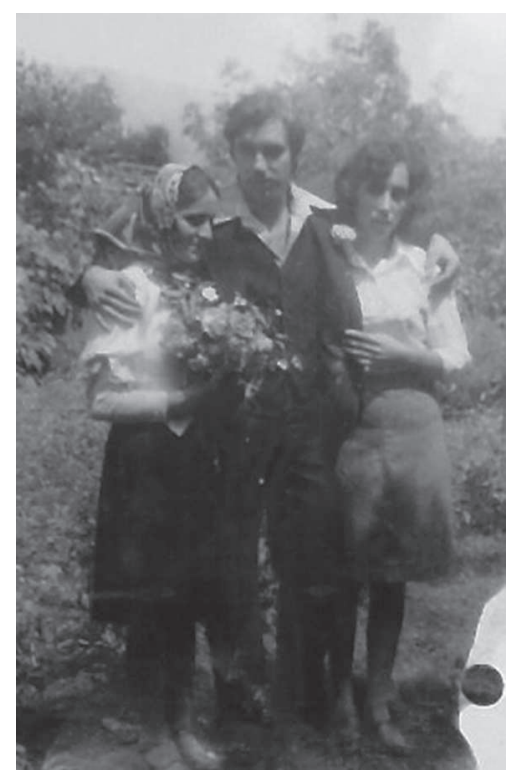

Казивао Милорад Радић.

\section{Лumepamypa}

Алексић К. Народне умотворине града Пећи и околине, І. 1970.

Бован В. Народна књижевност Срба на Косову, I-X. Приредио Владимир Бован. Приштина: Јединство, 1980.

Бован В. Народна књижевност Срба на Косову, Народне приповетке I, II. Приштина: Јединство, 1980.

Бован В. Српске народне умотворине са Косова и Метохије из рукописа Дене Дебељковића. Књига прва, лирске и епске народне песме, књига 6. Приредио Владимир Бован. Књига X, Одељење језичких и књижевних наука и уметности. Приштина: Академија наука и уметности Косова, 1984. 
Бован В. Јастребов у Призрену. Призрен: ДД Графика, 1996.

Бован В. Лирске и епске песме Косова и Метохије. Приредио Владимир Бован. Приштина - Београд - Исток: Институт за српску културу - Народно дело - Дом културе - Стручна књига, 2001.

Бован В. Народне приповетке и говорне умотворине са Косова и Метохије. Приштина-Лепосавић: Институт за српску културу, 2005.

Босанска вила. 1898.

Васиљевић М. Југословенски музички фолклор, І. Београд, 1950.

Веселиновић М. Поглед на Косово. Београд, 1895.

Врчевић В. Народне приповијести и пресуде из живота по Боки, Хериеговини и Црној Гори. Београд, 1890.

Вуксан Д. „Једна збирчица лирских народних пјесама.” Прилози проучавању народне поезије. Књ. V, св. 1-2 (1938).

Голуб. Календар. Цариград, 1895.

Дебељковић Д. „Косово. Обичаји народа српског.” Српски етнографски зборник, VII, 1907.

Дебељковић Д. Народне песме са Косова. Етнографска збирка архива САНУ, бр. 10, рукопис.

Дебељковић Д. Рукописна оставштина. Архив САНУ, улазни инвентар бр. 644, Emнографска збирка бр. 496.

Ђорђевић В. Српске народне мелодије (Јужна Србија). Скопље, 1928.

Ђорђевић В. Српске народне мелодије (предратна Србија). Београд, 1931.

Елезовић Г. Речник косовскометохијског дијалекта, књ. ІІ. Београд, 1935.

Јанковић Љ. Народне игре, књ. I-VIII. Београд, 1934, 1937, 1939, 1948-1952, 1964.

Ястребовъ И. С. Обычаи и пвесни турецкихъ Сербовъ (въ Призрвнъ, Ипекъ, Моравъ и Дебръ). С. Петербургъ, 1886.

Јуришић Г. Дечански првенаи, Нови Сад, 1852.

Караџић В. С. Народне српске пјесме, књ. І. Лајпциг, 1824.

Караџић В. С. Народне српске пјесме, књ. III. Беч, 1846.

Караџић В. С. Народне српске пјесме, књ. ІІ. Беч 1846.

Костић П. „Свадбени обичаји у Призрену.” Јужни преглед (1928).

Курипечић Б. Путопис кроз Босну, Србију, Бугарску и Румелију. Сарајево, 1950.

Манојловић К. „Свадбени иобичаји у Пећи.” Гласник Етнографског музеја у Београду (1933).

Милићевић М. Кнежевина Србија. Београд, 1876.

Милојевић С. М. Песме и обичаји укупног народа српског, I, II, III. Београд, 1869$1870,1875$.

Митропан П. „Прилог за историју српске штампе у Отоманском царству.” Обележја (1895).

Мокрањац С. Записи народних мелодија. Београд, 1966.

Мурко М. „За народном епиком на Косову.” Прилози за књижевност, језик, историју и фолклор, 1938.

Николский Д. Обычаи и пьсни турецкихъ сербовъ. Извъстия, 1886.

Нушић Б. Косово, опис земље и народа, I, II. Нови Сад, 1902-1903. 
Павловић М. Говор Сретечке жупе. Београд, 1939.

Петрановић Б. Српске народне пјесме из Босне и Хериеговине, I-III, Сарајево Београд, 1867-1870.

Пипин А. Обычаи и пъесни туреикихъ Сербовъ. Вьстник Эвропи, 1886.

Поповић Ј. Народни обичаји, умотворине и игре са Косова. Архив Матице српске у Новом Саду, бр. М. 7.538, рукопис.

Поповић Ј. Народни обичаји, умотворине и игре са Косова, Архив Матице српске, M, 7538.

Радоњић Ј. „Критовул, византиски историк.” Глас САНУ, књ. 80, 1930.

Ровински П. „.С. Ястребов, Обычаи и пъесни турецкихъ Сербовъ, С. Петербургъ, 1886", Журналъ Министарства народного просвещенія 1866, шестое десятилитіе, томъ XLVII, декабр.

Срећковић П. Синан Пама. Београд, 1865.

Урошевић А. Косово. Београд, 1965.

Филиповић М. „Епска песма о Средској.” Прилози проучавању народне поезије, 1934.

Цариградски гласник. Приредио Владимир Бован. Исток - Лепосавић: Дом културе „Свети Сава” Хвосно, 2006. Цариградски гласник, бр. 32, 1901.

Karadžić V. S. Montenegro und Montenegrinei. Stutgard, 1837.

Валентина Д. Питулич

\author{
УСТНОЕ НАРОДНОЕ ТВОРЧЕСТВО СЕРБОВ ИЗ КОСОВО И МЕТОХИИ ОТ ИВАНА \\ СТЕПАНОВИЧА ЯСТРЕБОВА ДО ПОСЛЕДНИХ ЗАПИСЕЙ
}

\title{
Резюме
}

В работе показано, как были записаны произведения устного народного творчества сербов из Косово и Метохии, учитывая общественно-исторические условия векового турецкого ига. Так как Старая Сербия - это край, в который сербы принесли со своей родины древние формы традиционной обрядовой практики, оказалось, что эта форма архаичного коллективного сознания имела большое значение в сохранении идентичности под властью турок. Принимая во внимание богатство устного повествования, русский консул Иван Степанович Ястребов первый систематически работал над сбором обычаев и песен сербов в этом крае, а до него Вук Стефанович Караджич в 1821 году в Крагуеваце записал несколько эпических песен одного исполнителя из Косово, Анджелко Вуковича.

В работе показано, что запись устного народного творчества в Косово и Метохии велась непрерывно, включая и печатные сборники устного народного творчества, и рукописные сборники, которые или остались в архивах Матицы сербской или Сербской академии наук и искусств, или имели счастье быть опубликованными. Значение записи устного наследия сербов из Косово и Метохии состоит в том, что в период после Второй мировой войны под давлением и из-за политики албанского населения в Косово и Метохии началось уничтожение всех форм сербской культуры, особенно того, что являлось хранителем идентичности. В этом плане значительным является труд Владимира Бована, который работал над сбором устного народного творчества и направлял своих студентов на полевых работах отмечать последние 
формы патриархальной культуры сербов. Таким образом спасено от забвения то, что иногда не могут спасти и важнейшие учреждения, а эту важную работу продолжили студенты Философского факультета в Косовска-Митровице в еще более тяжелых обстоятельствах, но с не меньшим успехом.

Ключевые слова: устное народное творчество, Иван Степанович Ястребов, лирика, эпика, устное народное творчество, коллектив, Старая Сербия, Косово и Метохия, фольклор. 